\title{
FALSE POSITIVE PHENOTYPIC DETECTION OF METALLO-BETA-LACTAMASES IN ACINETOBACTER BAUMANNII
}

\author{
Branka Bedenić ${ }^{1,2}$, Ranko Ladavac ${ }^{3}$, Mirna Vranić-Ladavac ${ }^{4}$, Nada Barišić ${ }^{4}$, Natalie Karčić ${ }^{4}$, \\ Katherina Bernadette Sreter ${ }^{5}$, Slobodan Mihaljević ${ }^{6}$, Luka Bielen ${ }^{7}$, Haris Car $^{8}$ and Nataša Beader ${ }^{1,2}$ \\ ${ }^{1}$ Department of Microbiology, School of Medicine, University of Zagreb, Zagreb, Croatia; \\ ${ }^{2}$ Department of Clinical and Molecular Microbiology, Zagreb University Hospital Centre, Zagreb, Croatia; \\ ${ }^{3}$ Department of Nephrology, Pula General Hospital, Pula, Croatia; ${ }^{4}$ Department of Microbiology, \\ Public Health Institute of Istria County, Pula, Croatia; ${ }^{5}$ Department of Clinical Immunology, \\ Pulmonology and Rheumatology, Sestre milosrdnice University Hospital Centre, Zagreb, Croatia; \\ ${ }^{6}$ Department of Anesthesiology, Zagreb University Hospital Centre, Zagreb, Croatia; \\ ${ }^{7}$ Department of Internal Medicine, Zagreb University Hospital Centre, Zagreb, Croatia; \\ ${ }^{8}$ Zagreb Secondary Medical School, Zagreb, Croatia
}

SUMMARY - Phenotypic detection of metallo- $\beta$-lactamases (MBLs) in Acinetobacter (A.) baumannii is a serious challenge to clinical microbiologists. MBLs are inhibited by metal chelators such as ethylenediaminetetraacetic acid) (EDTA). Production of MBLs cannot be recognized based on resistance phenotype. Therefore, phenotypic tests using EDTA are recommended. The aim of this study was to investigate the sensitivity and specificity of inhibitor based tests (EDTA) for detection of MBL. A total of 172 A. baumannii strains (123 carbapenemase positive and 49 carbapenemase negative) were analyzed. Phenotypic detection of MBLs was performed by the combined disk test with EDTA (CDT-EDTA) and EPI-dilution test (EPI-DT). Both tests were positive in all 11 isolates possessing VIM-1 MBL, showing 100\% sensitivity. However, false positive results were observed in strains with class D carbapenemases using both tests, i.e. all OXA-23 and OXA-24/40 producing organisms and most OXA-58 positive strains (77\% with CDT-EDTA vs. $65 \%$ with EPI-DT). False positive results can occur because oxacillinases are converted to a less active state in the presence of EDTA, leading to augmentation of the inhibition zone around the carbapenem disk or reduction of carbapenem minimum inhibitory concentrations. This study showed high sensitivity but low specificity of phenotypic methods in the detection of MBLs.

Key words: Beta-lactamases; Imipenem; Meropenem; Acinetobacter baumannii; Edetic acid

\section{Introduction}

Acinetobacter (A.) baumannii is a glucose non-fermentative gram-negative coccobacillus, considered a relevant nosocomial pathogen occurring particularly

Correspondence to: Branka Bedenic, $M D, P h D$, Department of Clinical and Molecular Microbiology, Zagreb University Hospital Centre, Kišpatićeva 12, HR-10000 Zagreb, Croatia;

E-mail: bbedenic@mef.hr, branka.bedenic@kbc-zagreb.hr

Received January 15, 2018, accepted March 20, 2018 in intensive care units (ICUs), as well as in burn therapy units ${ }^{1}$. The most frequent healthcare-associated infections are urinary tract infections, bacteremia, surgical site infections, and ventilator-associated pneumonia. A. baumannii strains become resistant to almost all antimicrobial agents, including carbapenems ${ }^{2}$. Beta-lactamase-mediated resistance is the most common mechanism of carbapenem resistance in this species. The most important mechanism of carbapenem resistance is the production of carbapenemases of class $\mathrm{A}$ 
$(\mathrm{KPC})^{3}$, class B (metallo-beta-lactamases: metallo- $\beta$ -lactamases (MBLs) of IMP, VIM or SIM family) ${ }^{4-8}$ or class D carbapenem-hydrolyzing class D carbapenemases (CHDL) ${ }^{9}$. However, Acinetobacter may develop resistance to carbapenems through various combined mechanisms, including decreased permeability, altered penicillin binding proteins (PBPs), and rarely, efflux pump overexpression ${ }^{10}$. The production of MBLs cannot be detected based on conventional susceptibility testing. Isolates co-harboring CHDL and MBLs have also been reported ${ }^{11-14}$, complicating the phenotypic detection. The genes encoding MBLs are located on integrons that frequently contain genes encoding extended spectrum beta-lactamases (ESBLs) and other resistance determinants, thus reducing therapeutic options ${ }^{15}$. Therefore, simple screening and inexpensive non-molecular methods need to be implemented in routine practice of diagnostic clinical laboratories. MBLs are inhibited by chelating agents such as ethylenediaminetetraacetic acid) (EDTA) and thiol compounds that are frequently used in inhibitor based detection methods ${ }^{16}$. Several tests have been proposed for the detection of MBLs in gram-negative bacteria with Epsilometer test (E-test) and combined disk test most commonly used ${ }^{8,16}$. However, there are concerns about the specificity of inhibitor-based tests, particularly in Pseudomonas aeruginosa ${ }^{17}$. False positive results have been reported because the chelating agents themselves increase membrane permeability and enhance the bactericidal effect. Recently, false positive phenotypic tests have also been described in $A$. baumannii $i^{14,18}$. However, there are no systematic studies to date on the reliability of inhibitor based tests for detecting MBLs in $A$. baumannii. The aim of this study was to assess the sensitivity and specificity of inhibitor based tests in the detection of MBLs in A. baumannii possessing VIM and CHDL, as well as to determine the accuracy of these non-molecular tests in distinguishing between MBLs and other carbapenemases.

\section{Materials and Methods}

\section{Bacteria}

A total of 172 (123 carbapenem-resistant and 49 carbapenem-susceptible) A. baumannii strains were collected in this multicenter study (Pula General Hospital, Zagreb University Hospital Centre, Varaždin
General Hospital, Sisak General Hospital, Merkur University Hospital, Dr Fran Mihaljević University Hospital for Infectious Diseases, Bjelovar General Hospital and Godan Nursing Home from Zagreb) during the 2009-2014 period from various clinical specimens and analyzed in our previous studies ${ }^{14,19-20}$.

\section{Susceptibility testing}

Susceptibility to imipenem and meropenem was tested by disk diffusion and broth microdilution test, and interpreted according to the CLSI criteria ${ }^{21-23}$.

\section{Detection of metallo- $\beta$-lactamases}

Phenotypic detection of MBLs was performed by combined disk test with the addition of EDTA and by EPI-broth microdilution test with the addition of 1,10-phenanthroline and EDTA $(0.5 \mathrm{mM})^{17,24-25}$. Augmentation of the inhibition zone around imipenem and meropenem disk by at least $7 \mathrm{~mm}$ in the presence of EDTA was considered to be a positive result in disk diffusion, whereas an 8-fold (three dilutions) reduction in the minimum inhibitory concentration (MIC) of imipenem or meropenem by EDTA was indicative of the production of MBL in dilution test. The genes encoding MBLs (IMP, VIM, NDM, SIM) and carbapenem-hydrolyzing oxacillinases were detected by polymerase chain reaction (PCR) and sequencing in previous studies ${ }^{14,19,20}$.

\section{Results}

\section{Susceptibility testing}

All carbapenemase positive strains, including MBL and CHDL were found to be resistant or intermediately susceptible to carbapenems with MICs of imipenem and meropenem ranging from 8 to $>128 \mathrm{mg} / \mathrm{L}$. The carbapenemase negative strains were predominantly susceptible or intermediately susceptible to carbapenems with 10 strains exhibiting resistance to meropenem due to the insertion sequence ISAba1 upstream of $b l a_{\text {OXA-51 }}$ gene.

\section{Characterization of beta-lactamases}

Twenty-seven strains were positive for $b l a_{\text {OXA-23 }}$-like,

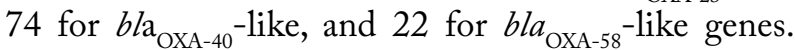


Eleven of the $b l a a_{\text {OXA-23 }}$-like positive isolates co-harbored $b l a_{\mathrm{VIM}-1}$ gene. Sequencing of representative bla genes revealed the presence of $b l a_{\mathrm{OXA}-23}, b l a_{\mathrm{OXA}-72}, b l a-$ OXA-58, and $b l a_{\mathrm{VIM}-1}$ genes. Forty-nine strains were negative for acquired carbapenemases and were used as negative control strains.

\section{Detection of metallo- $\beta$-lactamases}

Combined disk test with EDTA and EPI-dilution test were positive in all 11 isolates possessing VIM-1 MBL, showing sensitivity of $100 \%$, as illustrated in Table 1. However, false positive results in inhibitor based disk tests were observed in all OXA-23 and OXA-24/40 producing organisms with both disks, and in $77 \%$ and $73 \%$ of OXA-58 positive strains with imipenem and meropenem disk, respectively. Thus, the specificity of inhibitor based disk test was $0 \%$ for both OXA-23 and OXA-24/40, and 23\% and 27\% for OXA-58 producing strains, depending on the indicator disk. EPI dilution method yielded false positive results in all OXA-23 positive and OXA-24/40 positive strains and $68 \%$ of OXA-58 organisms (Table 1 ). For EPI-dilution test, the specificity was $0 \%$ for OXA23 and OXA-24/40 positive isolates and 32\% for OXA-58 producers. The carbapenemase negative strains yielded false positive results in disk test in 4 (8\%) and $5(10 \%)$ out of 49 strains with imipenem and meropenem disk, respectively. Only one strain demonstrated a false positive result in dilution method (2\%).

The augmentation of the inhibition zone around imipenem disk in the presence of EDTA ranged from 8 to $16 \mathrm{~mm}$ with a median of $11 \mathrm{~mm}$ for OXA-23 MBL negative strains, 8 to $17 \mathrm{~mm}$ for OXA-24/40 (median $14 \mathrm{~mm}$ ), and 4 to $18 \mathrm{~mm}$ for OXA-58 producers, as shown in Table 1. MBL positive strains showed an increase of the inhibition zone around imipenem disk of 8 to $15 \mathrm{~mm}$ (median $13 \mathrm{~mm}$ ), as seen in Table 1 . No significant increase of the inhibition zone was observed in carbapenemase negative strains ( 0 to $10 \mathrm{~mm}$, median $5 \mathrm{~mm}$ ).

The increase of the inhibition zone around the meropenem disk ranged from 9 to $17 \mathrm{~mm}$ for OXA-23 MBL negative strains (median $13 \mathrm{~mm}$ ), 8 to $17 \mathrm{~mm}$ for OXA-24/40 positive strains (median $15 \mathrm{~mm}$ ), and 5 to $19 \mathrm{~mm}$ for OXA-58 (median $13 \mathrm{~mm}$ ). The true MBL positive strains showed enlargement of the inhibition zone around imipenem disk ranging from 12 to $18 \mathrm{~mm}$ (median $16 \mathrm{~mm}$ ), as depicted in Table 1. Car-
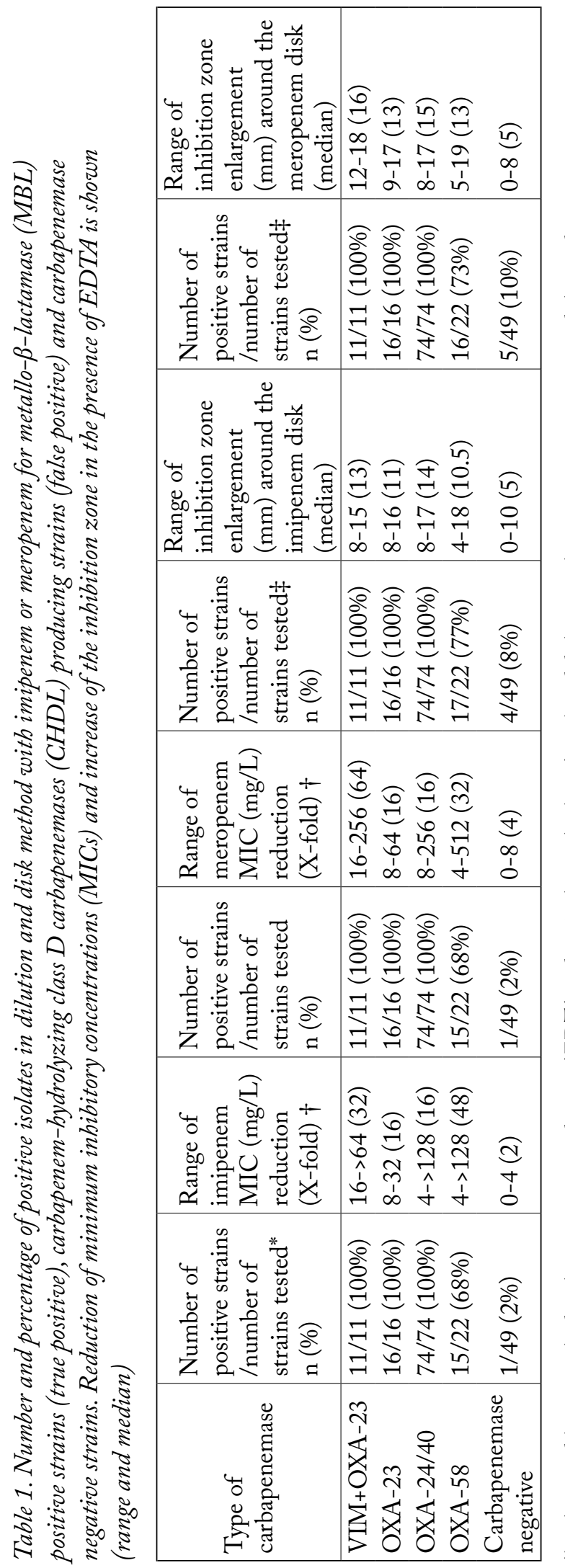
bapenemase negative strains yielded an increase of the inhibition zone around the imipenem disk ranging from 0 to $8 \mathrm{~mm}$ (median $5 \mathrm{~mm}$ ).

The median enlargement of the inhibition zone for imipenem was highest with true MBL positive strains and OXA-24 producers (14 $\mathrm{mm})$, followed by OXA23 positive strains $(11 \mathrm{~mm})$ and OXA-58 $(10.5 \mathrm{~mm})$. The median increase of the meropenem inhibition zone in the presence of EDTA was most pronounced with true MBL producers (16 mm) and OXA-24/40 positive strains $(15 \mathrm{~mm})$, followed by OXA-58 and OXA-23 (13 mm). EDTA embedded blank disks produced growth inhibition zones ranging from 4 to 7 $\mathrm{mm}$ due to the bactericidal effect of EDTA causing increased membrane permeability.

The positive predictive value of the combined disk test with imipenem disk among the carbapenemase positive isolates was very low $(9.48 \%)$ due to the very high number of false positive results. However, the negative predictive value was $100 \%$ with carbapenemresistant strains.

\section{Discussion}

Taken all together, the specificities of the combined disk test and EPI dilution test among OXA positive strains were very low ( $4.46 \%$ and $6.25 \%$, respectively). Their specificities for MBL detection were much higher among $A$. baumannii strains that were carbapenemase negative (91.8\% and $98 \%$, respectively). The difference between false positive rates of MBL detection with imipenem as indicator among OXA positive and carbapenemase negative $A$. baumannii strains was found to be statistically significant with both combined disk test and dilution method $(\mathrm{p}<0.001)$.

High sensitivity of inhibitor based tests was previously reported in $A$. baumanni $i^{26}$. However, specificity is a problem. EDTA caused a significant increase of the imipenem and meropenem inhibition zone, not only for MBL producers, but also for the CHDL positive isolates. False positive results in inhibitor based tests occur because in the presence of EDTA, oxacillinases are converted to a less active state leading to augmentation of the inhibition zone around the carbapenem disk and reduction of carbapenem MICs. This phenomenon was previously reported in $A$. baumannii $i^{18}$. The rate of false positive results in our study was highest among OXA-40 and OXA-23 positive isolates and much lower but still very high in OXA-58 positive isolates. This result can be explained by better hydrolysis of carbapenem substrates by OXA-40-like and OXA-23-like beta-lactamases and less efficient by OXA-58.

With combined disk test, differences in the percentages of false positive results between OXA-23 and OXA-58 and between OXA 24/40 and OXA-58 were statistically significant $(p<0.05$ and $p<0.001$, respectively), as were those with EPI-dilution test $(\mathrm{p}<0.05$ and $\mathrm{p}<0.001$, respectively). The study showed high sensitivity but low specificity of phenotypic methods in the detection of MBLs in A. baumannii and pointed to the necessity of molecular detection of MBL genes in $A$. baumannii by PCR. Low specificity was found only for CHDL positive organisms. The carbapenemase negative strains yielded only a few false positive results, demonstrating that the effect of EDTA on oxacillinases rather than the bactericidal effect of EDTA itself was responsible for the false positive results. There was no difference in the sensitivity and specificity of both methods with regard to the indicator antibiotic. Similar results were obtained with both carbapenems, imipenem and meropenem. According to our results, inhibitor based tests can distinguish MBL positive from carbapenemase negative, but not from CHDL positive organisms.

Unlike in $A$. baumannii, EDTA based disk test was shown to have high specificity in Enterobacteriaceae in distinguishing MBLs from KPC and OXA-48 ${ }^{27}$. Some authors recommend double-disk synergy test using two ceftazidime disks and a filter disk containing EDTA adjacent to one CAZ disk for detection of MBLs in Acinetobacter spp., Pseudomonas spp. and Enterobacteriaceae. Expansion of the inhibition zone between two ceftazidime disks indicates production of $\mathrm{MBL}^{24}$. According to some studies, supplementation of the EDTA disks with mercaptiopropionic acid as a thiol compound increases the sensitivity and specificity of the double-disk synergy test for detection of MBLs in A. baumannii and other gram-negative bacteria ${ }^{28}$.

The difficulty to detect MBLs in $A$. baumannii, variable MICs of carbapenems, together with their potential to disseminate, highlights the need for an accurate screening method. E-test MBL is an easy and simple but expensive method ${ }^{16}$. Inhibitor based test 
with EDTA, although inexpensive and simple to perform, lacks specificity. Dilution method is both laborious and time consuming, and was also shown to have low specificity. Molecular methods are expensive and require well-equipped laboratories and educated staff. Therefore, detection of MBLs in A. baumannii is a huge challenge to clinical microbiologists, particularly in isolates with multiple carbapenem-resistance mechanisms, such as those co-harboring CHDL and MBL. The difficulties with phenotypic detection have also been reported for OXA-48 $\beta$-lactamase in Enterobacteriacea $^{29}$.

\section{Acknowledgment}

This study was supported by grant BM 013, University of Zagreb, Croatia.

\section{References}

1. Bergogne-Bérézin E, Towner KJ. Acinetobacter spp. as nosocomial pathogens: microbiological, clinical, and epidemiological features. Clin Microbiol Rev. 1996;9(2):148-65.

2. Mammina C, Palma DM, Bonura C, Aleo A, Fasciana T, Sodano $\mathrm{C}$, et al. Epidemiology and clonality of carbapenem-resistant Acinetobacter baumannii from an intensive care unit in Palermo, Italy. BMC Res Notes. 2012;5:365, DOI: 10.1186/17560500-5-365

3. Robledo IE, Aquino EE, Santé MI, Santana JL, Otero, DM, León CF, et al. Detection of KPC in Acinetobacter spp. in Puerto Rico. Antimicrob Agents Chemother. 2010;54(3):1354-7, DOI: 10.1128/AAC.00899-09

4. Cornaglia G, Riccio ML, Mazzariol A, Lauretti L, Fontana R, Rossolini GM. Appearance of IMP-1 metallo-beta-lactamase in Europe. Lancet. 1999;353(9156):899-900, DOI: 10.1016/ S0140-6736(98)05954-6

5. Amudhan MS, Sekar U, Kamalanathan A, Balaraman S. Bla ${ }_{\mathrm{IMP}}$ and $b l a_{\mathrm{VIM}}$ mediated carbapenem resistance in Pseudomonas and Acinetobacter species in India. J Infect Dev Ctries. 2012;6(11): 757-62, DOI: $10.3855 /$ jidc. 2268

6. El-Ageery SM, Al-Hazmi SS. Microbiology and molecular detection of VIM-1 metallobetalactamase-producing Acinetobacter baumannii. Eur Rev Med Pharmacol Sci. 2014;18(7): 965-70.

7. Hrabák J, Stolbová M, Studentová V, Fridrichová M, Chudáčková E, Zemlickova H. NDM-1 producing Acinetobacter baumannii isolated from a patient repatriated to the Czech Republic from Egypt, July 2011. Euro Surveill. 2012;17(7), pii: 20085

8. Lee K, Yum CF, Yong D, Lee HM, Kim HD, Docquier JD, et al. Novel acquired metallo-beta-lactamase gene, $b l a_{\text {(SIM-1) }}$ in a class 1 integron from Acinetobacter baumannii clinical isolates from Korea. Antimicrob Agents Chemother. 2005;49(11): 4485-91, DOI: 10.1128/AAC.49.11.4485-4491.2005

9. Brown S, Amyes S. OXA (beta)-lactamases in Acinetobacter: the story so far. J Antimicrob Chemother. 2006;57(1):1-3, DOI: 10.1093/jac/dki425

10. Livermore DM, Woodford N. The beta-lactamase threat in Enterobacteriaceae, Pseudomonas and Acinetobacter. Trends Microbiol. 2006;14(9):413-20, DOI: 10.1016/j.tim.2006.07.008

11. Chatterjee S, Datta S, Roy S, Ramanan L, Saha A, Viswanathan $\mathrm{R}$, et al. Carbapenem resistance in Acinetobacter baumannii and other Acinetobacter spp. causing neonatal sepsis: focus on NDM-1 and its linkage to ISAba125. Front Microbiol. 2016; 7:1126, DOI: $10.3389 /$ fmicb.2016.01126

12. Kateete DP, Nakanjako R, Namugenyi J, Erume J, Joloba ML, Najjuka CF. Carbapenem resistant Pseudomonas aeruginosa and Acinetobacter baumannii at Mulago Hospital in Kampala, Uganda (2007-2009). Springerplus. 2016;5(1):1308, DOI: 10.1186/s40064-016-2986-7

13. Bošnjak Z, Plečko V, Budimir A, Mareković I, Bedenić B. First report of NDM-1-producing Acinetobacter guillouie. Chemotherapy. 2014;60(4):250-2, DOI: 10.1159/000381256

14. Bedenić B, Beader N, Godič-Torkar K, Vranić-Ladavac M, Luxner J, Veir Z, et al. Nursing home as a reservoir of carbapenem-resistant Acinetobacter baumannii. Microb Drug Resist. 2015;21(3):270-8, DOI: 10.1089/mdr.2014.0157

15. Walsh TR, Toleman MA, Poirel L, Nordmann P. Metallo-beta-lactamases: the quiet before the storm? Clin Microbiol Rev. 2005;18(2):306-25, DOI: 10.1128/CMR.18.2.306-325.2005

16. Walsh TR, Bolmström A, Qwärnström A, Gales A. Evaluation of a new Etest for detecting metallo-beta-lactamases in routine clinical testing. J Clin Microbiol. 2002;40(8):2755-9, DOI: 10.1128/JCM.40.8.2755-2759.2002

17. Ratkai C, Quinteira S, Grosso F, Monteiro N, Nagy E, Peixe L. Controlling for false positives: interpreting MBL Etest and MBL combined disc test for the detection of metallo-betalactamases. J Antimicrob Chemother. 2009;64(3):657-8, DOI: 10.1093/jac/dkp229

18. Villalón P, Valdezate S, Medina-Pascual MJ, Rubio V, Vindel A, Saez-Nieto JA. Clonal diversity of nosocomial epidemic Acinetobacter baumannii strains isolated in Spain. J Clin Microbiol. 2011;49(3):875-82, DOI: 10.1128/JCM.01026-10

19. Vranić-Ladavac M, Bedenić B, Minandri F, Ištok M, Bošnjak $Z$, Frančula-Zaninović $\mathrm{S}$, et al. Carbapenem resistance and acquired class D beta-lactamases in Acinetobacter baumannii from Croatia 2009-2010. Eur J Clin Microbiol Infect Dis. 2014;33(3):471-8, DOI: 10.1007/s10096-013-1991-9

20. Ladavac R, Bedenić B, Vranić-Ladavac M, Barišić N, Karčić N, Pompe K, et al. Emergence of different Acinetobacter baumannii clones in a Croatian hospital and correlation with antibiotic susceptibility. J Glob Antimicrob Resist. 2017;10:213-8, DOI: 10.1016/j.jgar.2017.07.001 
21. Clinical and Laboratory Standards Institute. Performance standards for antimicrobial disk susceptibility testing. Approved $10^{\text {th }}$ edition. CLSI document M02-A10. Clinical and Laboratory Standards Institute, Wayne, PA; 2009.

22. Clinical and Laboratory Standards Institute. Twentieth informational supplement. (June 2010 update). CLSI document M100-S20. Clinical and Laboratory Standards Institute, Wayne, PA; 2010.

23. Clinical and Laboratory Standards Institute. Performance standards for antimicrobial susceptibility testing. $24^{\text {th }}$ informational supplement. M100-S24 Clinical and Laboratory Standards Institute, Supplement M100S, Wayne, PA; 2014.

24. Arakawa Y, Shibata N, Shibayama K, Kurokawa H, Yagi T, Fujiwara $\mathrm{H}$, et al. Convenient test for screening metallo-beta-lactamase-producing gram-negative bacteria by using thiol compounds. J Clin Microbiol. 2000; 38(1):40-3.

25. Migliavacca R, Docquier JD, Mugnaioli C, Amicosante G, Daturi R, Lee K, et al. Simple microdilution test for detection of metallo-beta-lactamase production in Pseudomonas aeruginosa.
J Clin Microbiol. 2002;40(11):4388-90. DOI: 10.1128/ JCM.40.11.4388-4390.2002

26. Anwar M, Ejaz H, Zafar A, Hamid H. Phenotypic detection of metallo-beta-lactamases in carbapenem resistant Acinetobacter baumannii isolates from pediatric patients in Pakistan. J Pathog. 2016;2016:8603964, DOI: 10.1155/2016/8603964

27. Pluquet E, Arlet G, Bingen E, Drieux L, Mammeri H. Sensitive and specific phenotypic assay for metallo-beta-lactamase detection in Enterobacteria by use of moxalactam disk supplemented with EDTA. J Clin Microbiol. 2011;49(7):2667-70, DOI: 10.1128/JCM.00328-11

28. Kim SY, Hong SG, Moland ES, Thomson KS. Convenient test using a combination of chelating agents for detection of metallo-beta-lactamases in the clinical laboratory. J Clin Microbiol. 2007;45(9):2798-801, DOI: 10.1128/JCM.02486-06

29. Jajić I, Benčić A, Siroglavić M, Zarfel G, Ružić B, Pezelj I, Bedenić B. Klebsiella pneumoniae OXA-48 in a urology patient: a case report. Acta Clin Croat. 2017;56(1):166-71. DOI: 10.20471/acc.2017.56.01.23

Sažetak

\title{
LAŽNO POZITIVNA FENOTIPSKA DETEKCIJA METALO-BETA-LAKTAMAZA U ACINETOBACTER BAUMANNII
}

\author{
B. Bedenic, R. Ladavac, M. Vranić-Ladavac, N. Barišić, N. Karčić, K.B. Sreter, \\ S. Mihaljevic, L. Bielen, H. Car i N. Beader
}

Fenotipska detekcija metalo- $\beta$-laktamaza (MBL) u Acinetobacter (A.) baumannii je velik izazov kliničkim mikrobiolozima. MBL su inhibirane metalnim kelatorima kao što je etilendiamin tetraoctena kiselina (EDTA). Produkcija MBL ne može se prepoznati na temelju fenotipa rezistencije. Zbog toga se preporuča primjena fenotipskih testova koji rabe metalne kelatore kao što je EDTA. Cilj istraživanja bio je utvrditi osjetljivost i specifičnost testova s inhibitorom (EDTA) u otkrivanju MBL u A. baumannii. Analizirana su 172 izolata A. baumannii (123 karbapenemaza pozitivnih i 49 karbapenemaza negativnih). Fenotipska detekcija MBL je provedena metodom kombiniranih diskova (EDTA CDT-EDTA) i EPI-dilucijskom metodom (EPI-DT). Oba testa su bila pozitivna u svih 11 izolata pozitivnih na VIM-1 MBL, što odgovara osjetljivosti od 100\%. Lažno pozitivni rezultati su dobiveni u karbapenem-rezistentnim izolatima pozitivnim na klasu D karbapenemaza u oba testa: svi OXA-23 i OXA-24/40 kao i većina OXA-58 pozitivnih sojeva (77\% u CDT-EDTA i 65\% u EPI-DT). Lažno pozitivni rezultati u testovima s inhibitorom nastaju zbog toga što oksacilinaze prelaze u stanje manje aktivnosti u prisustvu EDTA, što dovodi do smanjenja minimalne inhibitorne koncentracije karbapenema ili do uvećanja zone oko diska karbapenema. Studija je pokazala visoku osjetljivost, ali nisku specifičnost fenotipskih testova za dokaz MBL u A. baumannii, što ukazuje na neophodnost korištenja molekularnih metoda.

Ključne riječi: Beta-laktamaze; Imipenem; Meropenem; Acinetobacter baumannii; Etilen-diamin tetraoctena kiselina 